\title{
Pemahaman Konsep Struktur Atom Setelah Pembelajaran Menggunakan Model Discovery Learning Berbantuan LKS pada Siswa Kelas X MIA-1 SMA Negeri 1 Paku
}

\author{
Indraniyati*, Abdul Hadjranul Fatah, Nopriawan Berkat Asi \\ Program Studi Pendidikan Kimia, Jurusan Pendidikan MIPA, FKIP, Universitas \\ Palangka Raya, Indonesia \\ e-mail: indraniyati@gmail.com
}

Diterima: 06 Maret 2020; Disetujui: 21 Maret 2020; Diterbitkan: 30 Maret 2020

\begin{abstract}
ABSTRAK
Model Discovery Learning merupakan nama lain dari pembelajaran penemuan. Sesuai dengan namanya, model ini mengarahkan siswa untuk dapat menemukan sesuatu melalui proses pembelajaran yang dijalaninya. Siswa diarahkan untuk terbiasa menjadi saintis. Tujuan penelitian ini adalah untuk mendeskripsikan pemahaman konsep struktur atom: partikel penyusun inti atom, nomor atom, nomor massa, isotop, isoton, dan isobar. Setelah pembelajaran menggunakan model Discovery Learning berbantuan LKS pada Siswa Kelas X MIA-1 SMA Negeri 1 Paku, Barito Timur TahunAjaran 2017/2018. Penelitian ini melibatkan 25 siswa kelas X MIA-1 SMA Negeri 1 Paku, Barito Timur. Data hasil pemahaman konsep siswa diperoleh melalui pemberian tes tertulis berbentuk essay (uraian) terhadap siswa sebelum dan sesudah menggunakan model Discovery Learning, lembar pengamatan pengelolaan pembelajaran, lembar aktivitas belajar siswa menggunakan rubrik penilaian aktivitas kelompok. Data dianalisis dengan teknik deskriptif. Hasil penelitian menunjukkan bahwa sebagian besar pemahaman konsep siswa sudah benar menuliskan dan menjelaskan simbol atom sebagai lambang unsur yang dilengkapi dengan nomor atom dan nomor massa berjumlah $80 \%$. Mendeskripsikan pengertian nomor atom (jumlah proton) sebagai identitas suatu unsur berjumlah $77,33 \%$. Mendeskripsikan pengertian nomor massa sebagai jumlah proton dan neutron dalam suatu inti atom berjumlah $68 \%$. Menuliskan nomor massa, jumlah proton, jumlah neutron, jumlah elektron pada unsur yang diketahui notasinya berjumlah $69,33 \%$, menjelaskan pengertian isotop, isobar, isoton berjumlah 74,66\%. Rata-rata pemahaman konsep siswa pada materi struktur atom berjumlah 73,86\%.
\end{abstract}

Kata Kunci: discovery learning, pemahaman, struktur atom.

\section{PENDAHULUAN}

Pendidikan adalah usaha sadar dan terencana untuk mewujudkan suasana belajar dan proses pembelajaran agar peserta didik secara aktif mengembangkan potensi dirinya untuk memiliki kekuatan spiritual keagamaan, pengendalian diri, kepribadian, kecerdasan, akhlak mulia, serta keterampilan yang diperlukan dirinya, masyarakat, bangsa dan negara (UU No.20, Tahun 2003).

Kimia adalah ilmu yang mencari jawaban atas apa, mengapa, dan bagaimana gejala-gejala alam yang berkaitan dengan komposisi, struktur, dan sisfat, perubahan, dinamika, dan energitika zat. Oleh sebab itu, mata pelajaran kimia di SMA/MA mempelajari segala sesuatu tentang zat yang melibatkan 
ketrampilan dan penalaran. Ada dua hal yang berkaitan dengan kimia yang tidak bisa dipisahkan, yaitu kimia sebagai produk (pengetahuan kimia yang berupa fakta, konsep, prinsip, hukum, dan teori) dan kimia sebagai proses yaitu kerja ilmiah (Mulyasa).

Pelajaran kimia merupakan salah satu pelajaran yang memiliki karakteristik tersendiri dan memerlukan keterampilan dalam memecahkan masalah-masalah ilmu kimia yang berupa teori, konsep, hukum, dan fakta. Salah satu tujuan pembelajaran ilmu kimia di SMA adalah agar siswa memahami konsep-konsep kimia dan saling keterkaitannya serta penerapannya baik dalam kehidupan sehari-hari maupun teknologi. Oleh sebab itu, siswa diharapkan mampu memahami dan menguasai konsep-konsep kimia (Depdiknas, 2013).

Berhasil tidaknya suatu proses pembelajaran tidak terlepas dari peran guru didalamnya. Oleh karena itu, guru sebagai pengelola pembelajaran dituntut mampu mencari usaha yang dapat membangkitkan siswa. Guru adalah pendidik profesional dengan tugas utama mendidik, mengajar, membimbing, mengarahkan, melatih, menilai, dan mengevaluasi peserta didik pada pendidikan anak usia dini jalur pendidikan formal, pendidikan dasar, dan pendidikan menengah (UU No.14 Tahun 2005).

Keberhasilan siswa tidak terlepas dari peranan guru sebagai mediator dalam proses belajar mengajar. Demi kelancaran kegiatan belajar mengajar, seorang guru haruslah dapat berhasil dengan baik, efektif dan efisien. Menurut Nasution S (1988: 36), suatu pengajaran dikatakan berhasil baik, apabila pengajaran itu membangkitkan proses belajar mengajar yang kreatif dan efesien. Salah satu pertimbangan yang memungkinkan untuk itu adalah penggunaan alat pengajaran.

Media merupakan salah satu alat bantu bagi guru dalam menyajikan dan memperjelas materi pelajaran dan membantu siswa dalam memahami apa yang disajikan. Media merupakan rangkuman materi, sehingga bagi siswa dapat membantunya dalam mengikuti alur penjelasan karena sajian tidak hanya dalam uraian bahasa (kata-kata).

Pemilihan media pun tidak terlepas dari konteks bahwa media merupakan komponen sistem intruksional secara keseluruhan. Meski tujuan dan materi telah diketahui, tanpa adanya pertimbangan sumber bahan media pengajaran ada di dalamnya, maka strategi mengajar masih perlu dipertimbangkan. Misalnya materi struktur atom yang cenderung bersifat abstrak.

Hasil penelitian yang dilakukan oleh Gina Febria (2014) mengungkapkan tentang pengaruh penggunaan LKS terhadap pemahaman konsep siswa pada materi tatanama senyawa dan persamaan reaksi kimia pada siswa kelas XI SMAN 2 Palangka Raya menyimpulkan bahwa penggunaan LKS efektif untuk membantu pemahaman konsep siswa. Penelitian tentang pemahaman konsep sifat jari-jari atom telah dilakukan Meiliawati (2019) pada pembelajaran menggunakan discovery learning menunjukkan $89 \%$ siswa belum memahami konsep.

Hasil penelitian yang dilakukan Tri (2014) tentang pembelajaran dengan menggunakan LKS mampu meningkatkan pemahaman konsep siswa tentang konsep reaksi reduksi dan oksidasi dalam menentukan biloks spesi dan sesudah reaksi dalam suatu persamaan reaksi redoks. Hal ini terbukti dengan adanya $100 \%$ peningkatan pemahaman siswa yang menjawab benar pada tahap akhir pembelajaran. Hasil penelitian Dedeh Kalungkung (2013) tentang pengaruh 
penerapan metode Seven Jump Method (SJM) dengan pendekatan Problem Based Learning (PBL) terhadap peningkatan pemahaman konsep siswa pada materi minyak bumi dan gas alam, terlihat dari persentase ketuntasan tiap indikator.

Berikut adalah rekaman hasil pembelajaran siswa pada materi struktur atom.

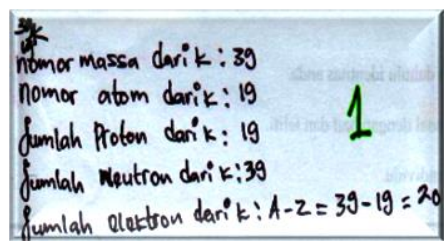

Berdasarkan hasil observasi serta penjelasan dan permintaan guru mata pelajaran kimia di sekolah SMAN 1 Paku Kabupaten Barito Timur bahwa kebanyakan siswa masih kesulitan pada materi struktur atom khususnya menentukan partikel penyusun inti atom, mendefinisikan nomor atom, nomor massa, isitop, isoton, isobar dan karena tidak pernah dilakukan penelitian di sekolah SMAN 1 Paku, maka oleh sebab itu Peneliti tertarik untuk melakukan penelitian tentang "Pemahaman Konsep Struktur Atom Pada Siswa Kelas X MIA1 SMAN 1 Paku Kabupaten Barito Timur Setelah Pembelajaran Menggunakan Model Discovery Learning Berbantuan LKS Tahun Ajaran 2017/2018”.

Fokus Penelitian ini adalah pemahaman konsep struktur atom setelah pembelajaran menggunakan model Discovery Learning berbantuan LKS pada siswa kelas X MIA-1 SMA Negeri 1 Paku Kabupaten Barito Timur Tahun Ajaran 2015/2016. Rumusan masalah dalam penelitian ini adalah bagaimana pemahaman konsep siswa pada materi "Struktur Atom Kelas X MIA-1 SMAN 1 Paku Kabupaten Barito Timur Setelah Pembelajaran Menggunakan Model Discovery Learning Berbantuan LKS Tahun Ajaran 2017/2018? Tujuan yang ingin dicapai pada penelitian ini adalah untuk mengetahui Pemahaman Konsep Siswa pada Materi "Struktur Atom Pada Siswa Kelas X MIA-1 SMAN 1 Paku Kabupaten Barito Timur Setelah Pembelajaran Menggunakan Model Discovery Learning Berbantuan LKS Tahun Ajaran 2017/2018”.

\section{METODOLOGI PENELITIAN}

Penelitian ini termasuk pada jenis penelitian yang menggunakan metode deskriptif. Penelitian deskriptif direncanakan untuk memperoleh informasi tentang status gejala saat penelitian dilakukan. Penelitian ini diarahkan untuk menetapkan sifat status pada waktu penyelidikan itu dilakukan. Dalam penelitian deskriptif, tidak ada perlakuan yang diberikan atau dikendalikan seperti yang dapat ditemui dalam penelitian eksperimen. Tujuan penelitian ini adalah untuk melukiskan variabel atau kondisi "apa yang ada" dalam suatu situasi (Furchan, 2011).

Latar penelitian dilaksanakan di SMA Negeri 1 Paku Kabupaten Barito Timur. sehingga siswa dapat memperoleh konsep yang benar dalam proses pembelajaran. Subjek penelitian ini adalah siswa kelas X MIA-1 semester ganjil SMA Negeri 1 Paku Kabupaten Barito Timur Tahun Pelajaran 2017/2018 yang berjumlah 25 siswa.

Tahap persiapan ini meliputi perizinan, observasi sekolah, penyusunan dan validasi instrumen penelitian, dan simulasi pembelajaran yang dilakukan di kelas X MIA-2 SMA Negeri 1 Paku Kabupaten Barito Timur Menggunakan Model Discovery Learning Berbantuan LKS. 
Tabel 1. Data yang Diperoleh dan Instrumen yang Digunakan

\begin{tabular}{ll}
\hline \multicolumn{1}{c}{ Data yang Diperoleh } & \multicolumn{1}{c}{ Instrumen } \\
\hline Pemahaman konsep siswa & $\begin{array}{l}\text { Soal tes pemahaman konsep (pretes dan } \\
\text { postes) }\end{array}$ \\
Pengelolaan Pembelajaran & $\begin{array}{l}\text { Lembar pengamatan pengelolaan } \\
\text { pembelajaran. }\end{array}$ \\
Aktivitas siswa dalam pembelajaran & $\begin{array}{l}\text { Lembar pengamatan aktivitas belajar } \\
\text { siswa yang menggunakan pedoman } \\
\text { penilaian berupa rubrik penilaian } \\
\text { aktivitas kelompok. }\end{array}$ \\
\hline
\end{tabular}

1. Soal tes pemahaman konsep Partikel Penyusun atom, Nomor atom, Nomor massa, Isotop, Isoton, dan Isobar. Instrumen penelitian berupa soal tes pemahaman yang divalidasi oleh 2 orang rater yaitu Dosen Program Studi Pendidikan Kimia Universitas Palangka Raya dan guru mata pelajaran Kimia SMA Negeri 1 Paku Barito Timur. Validasi yang dilakukan meliputi validasi isi atau cakupan materi yang akan diujikan. Hal tersebut bertujuan untuk mengetahui informasi tentang kualitas tes uraian yang berbentuk essay. Validasi yang dilakukan meliputi validasi isi yaitu pengukuran terhadap sebuah tujuan khusus tertentu yang sejajar dengan materi atau isi ajaran yang diberikan berdasarkan Kurikulum pembelajaran.

Tabel 2. Kisi-kisi Tes Pemahaman Konsep

\begin{tabular}{|c|c|c|}
\hline \multirow[b]{2}{*}{\begin{tabular}{l}
\multicolumn{1}{c}{ Kompetensi Dasar } \\
Memahami struktur atom \\
berdasarkan teori atom \\
Bohr, sifat-sifat unsur, \\
massa atom relatif, dan \\
sifat-sifat periodik unsur \\
dalam tabel periodikserta \\
menyadari \\
keteraturannya, melalui \\
pemahaman konfigurasi \\
elektron.
\end{tabular}} & Indikator & Butir Soal \\
\hline & $\begin{array}{l}\text { 1. } \begin{array}{l}\text { Menjelaskan simbol atom } \\
\text { sebagai lambang unsur yang } \\
\text { dilengkapi dengan nomor } \\
\text { atom dan nomor massa. }\end{array} \\
\text { 2. Mendeskripsikan pengertian } \\
\text { nomor atom (jumlah proton) } \\
\text { sebagai identitas atom suatu } \\
\text { unsur } \\
\text { 3. Mendeskripsikan pengertian } \\
\text { nomor massa, sebagai jumlah } \\
\text { proton dan neutron dalam } \\
\text { suatu inti atom. } \\
\text { 4. Menuliskan nomor massa, } \\
\text { jumlah proton, jumlah } \\
\text { neutron, dan jumlah elektron } \\
\text { pada unsur yang diketahui } \\
\text { notasinya. } \\
\text { Menjelaskan pengertian } \\
\text { Isotop, Isobar, dan Isoton }\end{array}$ & $\begin{array}{l}\text { Soal nomor } 1 \\
\text { (pretes dan } \\
\text { postes) }\end{array}$ \\
\hline
\end{tabular}
berikut:

Skala pemberian skor validasi isi soal tes pemahaman konsep yaitu sebagai

Skor "2" apabila soal sudah komunikatif dan sesuai dengan tujuan pembelajaran. Skor "1" apabila soal sudah komunikatif tetapi belum sesuai dengan tujuan pembelajaran atau sebaliknya. 
Skor "0" apabila soal tidak komunikatif dan tidak sesuai dengan tujuan pembelajaran.

Validator diminta untuk memberikan penilaian terhadap butir soal yang dititik beratkan pada penggunaan kalimat yang digunakan (sudah komunikatif atau belum) serta kesesuian dengan konsep-konsep yang akan diteliti. Instrumen yang digunakan dalam penelitian ini berupa tes pemahaman dalam bentuk essay dengan soal yang berjumlah 5 butir soal.

Lembar pengamatan pengelolaan pembelajaran menggunakan model Discovery Learning berbantuan LKS untuk mengetahui keterlaksanaan proses pembelajaran yang dilakukan guru. Aspek yang diamati pada lembar pengamatan pengelolaan pembelajaran tersebut terdiri dari 7 aspek yaitu guru memberikan pretes secara individual kepada siswa, guru memberikan LKS yang dikerjakan secara berkelompok, guru membimbing siswa untuk bersama-sama membahas hasil belajar individu dalam kelompok belajar, guru mengarahkan dan memberikan penegasan pada materi pembelajaran yang telah dipelajari, guru memberikan postes pada siswa untuk dikerjakan secara individu, dan guru memberikan penghargaan kepada kelompok berdasarkan hasil belajar kelompok yang terbaik. Lembar pengamatan pengelolaan pembelajaran menggunakan Model Discovery Learning berbantuan LKS bertujuan untuk mengetahui keterlaksanaan proses pembelajaran yang dilakukan guru pada materi Struktur Atom. Aspek yang diamati pada lembar pengamatan pengelolaan pembelajaran tersebut terdiri dari 16 aspek. Hasil pengelolan pembelajaran disajikan pada lampiran.

Lembar pengamatan terhadap aktivitas belajar kelompok siswa dalam kegiatan pembelajaran pada pelaksanaan penelitian ini bertujuan untuk mengamati aktivitas siswa kegiatan belajar mengajar yang sedang berlangsung berdasarkan lembar pengamatan aktivitas siswa dalam kegiatan pembelajaran menggunakan Model Discovery Learning yang terdiri dari 4 aspek. Hasil pengamatan terhadap aktivitas belajar masing-masing kelompok siswa dalam pembelajaran disajikan pada lampiran.

Sebelum melakukan penelitian maka terlebih dahulu dilakukan simulasi pembelajaran di kelas X MIA-2 SMA Negeri 1 Paku Barito Timur. Hal ini dilakukan untuk dapat mengetahui ketersediaan waktu, keterbacaan LKS yang diberikan, dan keterlaksanaan pembelajaran menggunakan model Discovery Learning. Simulasi pembelajaran tersebut meliputi pelaksanaan pembelajaran yang akan diteliti yaitu pelaksanaan pretes, pemberian LKS dan postes.

Selanjutnya dilakukan pengumpulan data yang diperlukan untuk menjawab masalah penelitian ini. Kegiatan ini meliputi pretes, pembelajaran dengan menggunakan model Discovery Learning berbantuan LKS dan postes di kelas X MIA-1 SMA Negeri 1 Paku Barito Timur.

Data yang dikumpulkan dari penelitian ini, yaitu 1) hasil tes pemahaman konsep siswa bentuk essay pada pretes dan postes; 2) pengelolaan pembelajaran menggunakan model Discovery Learning berbantan LKS; dan 3) aktivitas belajar kelompok.

Data yang diperoleh dalam penelitian ini berupa hasil pemahaman konsep siswa melalui pretes, hasil postes, pembelajaran berbantuan LKS, dan lembar pengamatan aktivitas siswa (rubrik penilaian aktivitas siswa dan kelompok). Berikut ini teknik analisis data yang diperoleh: 
Analisis data pemahaman konsep dilakukan dengan langkah-langkah berikut: (1).Memberikan skor pada masing-masing siswa, semua jawaban siswa baik pretes dan postes di korelasikan dan diberi skor berdasarkan deskripsi pemahaman konsep dan skor setiap butir soal. Hasil skor yang diperoleh untuk mengetahui tingkat pemahaman konsep menggunakan model Discovery Learning berbantuan LKS pada materi Partikel Penyusun atom, Nomor atom, Nomor massa, Isotop, Isoton, dan Isobar. Deskripsi pemahaman konsep dan skor setiap butir soal pemahaman konsep pada materi Partikel Penyusun atom, Nomor atom, Nomor massa, Isotop, Isoton, dan Isobar. (2). Mengkonversi total skor pretes dan postes masing-masing siswa dalam bentuk persentase pemahaman konsep dengan cara :

$\%$ pemahaman konsep siswa $=\frac{\text { Jumlahskor " } n \text { " yangdiperoleh }}{\text { Jumlahskortotal }} \times 100 \%$

Hasil persentase pemahaman yang diperoleh siswa diberikan keterangan apakah siswa tersebut sudah mencapai nilai ketutantasan atau belum berdasarkan KKM. Persentase pemahaman konsep siswa pada setiap indikator dapat ditelusuri dengan menganalisis pola jawaban siswa pada pretes dan postes. Peningkatan pemahaman konsep dihitung menggunakan rumus Normalitas gain. Gain adalah selisih nilai postes dan pretes, gain menunjukkan peningkatan pemahaman siswa setelah pembelajaran dilakukan. Dimana untuk menghitung nilai gain digunakan rumus gain yaitu :

$$
\mathrm{g}=\frac{\mathrm{S}_{\text {postes }}-\mathrm{S}_{\text {prets }}}{\text { skor maksimum }-\mathrm{S}_{\text {pretes }}} \times 100
$$

Persentase peningkatan setiap indikator digolongkan ke dalam kategori sesuai Tabel.5.

Tabel 3. Nilai Konversi Peningkatan Pemahaman

\begin{tabular}{ll}
\hline Besar Persentase & Kategori \\
\hline $\mathrm{g} \geq 70$ & Tinggi \\
$70>\mathrm{g} \geq 30$ & Sedang \\
$\mathrm{g}<30$ & Rendah \\
\hline
\end{tabular}

1. Mengurutkan skor siswa pada pretes dari nilai terendah hingga tertinggi ke dalam tabel, kemudian dari tabel tersebut di buat kurva perubahan skor pada pretes dan postes dengan mengacu pada KKM untuk mengetahui sejauh mana peningkatan pemahaman konsep siswa.

2. Menafsirkan jawaban siswa berdasarkan pola jawaban pada masing-masing skor setiap indikator.

Analisis data pengelolaan pembelajaran diperoleh dari lembar pengamatan pengelolaan pembelajaran menggunakan model Discovery Learning berbantuan LKS untuk mengetahui keterlaksanaan proses pembelajaran yang dilakukan guru yang diamati oleh satu pengamat yaitu Guru mata pelajaran kimia di sekolah SMAN 1 Paku. Aspek yang diamati pada lembar pengamatan pengelolaan pembelajaran tersebut terdiri dari 16 aspek. Persentase pengelolaan pembelajaran dengan menggunakan model Discovery Learning berbantuan LKS dapat dihitung dengan menggunakan rumus sebagai berikut:

Konversi nilai $=\frac{\text { Jumlah skor perolehan }}{\text { Jumlah skor maksimum }} \times 100 \%$ 
Tabel 4. Nilai Konversi Pengelolaan Pembelajaran

\begin{tabular}{cl}
\hline Nilai Konversi $(\%)$ & \multicolumn{1}{c}{ Kategori } \\
\hline $80-100$ & Sangat Baik \\
$60-79$ & Baik \\
$40-59$ & Cukup Baik \\
$0-39$ & Kurang Baik \\
\hline
\end{tabular}

(Sumber: Kunandar, 2014 dikutip dalam Rapita (2016))

Analisis data aktivitas kelompok siswa diperoleh dari lembar pengamatan terhadap aktivitas kelompok siswa dalam kegiatan pembelajaran. Pelaksanaan penelitian ini bertujuan untuk mengamati aktivitas siswa dalam kelompok pada saat pembelajaran berlangsung yang mana proses ini pun dibantu oleh dua orang pengamat dengan memberikan penilaian berdasarkan rubrik penilaian aktivitas belajar. Kategori yang diberikan dalam penilaian adalah skor 1 (sangat kurang baik), skor 2 (kurang baik), skor 3 (cukup baik), skor 4 (baik) dan skor 5 (sangat baik).

Adapun rumus perhitungan untuk memperoleh persentase aktivitas siswa dalam pembelajaran menggunakan model Discovery Learning Berbantuan LKS adalah sebagai berikut :

Konversi nilai $=\frac{\text { Jumlah skor perolehan }}{\text { Jumlah skor maksimum }} \times 100 \%$

Tabel 5. Nilai Konversi Aktivitas Kelompok Siswa dalam Pembelajaran

\begin{tabular}{cl}
\hline Nilai Konversi (\%) & \multicolumn{1}{c}{ Kategori } \\
\hline $80-100$ & Sangat Baik \\
$60-79$ & Baik \\
$40-59$ & Cukup Baik \\
$0-39$ & Kurang Baik \\
\hline
\end{tabular}

(Sumber : Kunandar, 2013)

\section{HASIL PENELITIAN DAN PEMBAHASAN}

Pada bagian deskripsi data ini akan mendeskripsikan antara lain pelaksanaan pembelajaran, aktivitas pembelajaran, dan skor pretes dan postes. Data pretes dan postes diperoleh melalui tes pemahaman konsep yang terdiri dari 5 soal essay.

Tabel 6. Data Persentase Pemahaman Konsep Siswa Pada Pretes

\begin{tabular}{|c|c|c|c|c|c|c|c|c|}
\hline \multirow[t]{2}{*}{ No. } & \multirow{2}{*}{$\begin{array}{l}\text { Skor } \\
\text { soal) }\end{array}$} & \multicolumn{2}{|c|}{ jawaban } & \multicolumn{2}{|c|}{ siswa } & \multirow{2}{*}{$\begin{array}{l}\text { Total } \\
\text { skor }\end{array}$} & \multirow{2}{*}{$\begin{array}{c}\text { Pemahama } \\
\text { n konsep } \\
(\%)\end{array}$} & \multirow{2}{*}{$\begin{array}{c}\text { Kategor } \\
\mathbf{i}\end{array}$} \\
\hline & & 2 & 3 & 4 & 5 & & & \\
\hline 1 & 1 & 0 & 0 & 2 & 1 & 4 & 26,66 & $\begin{array}{l}\text { Kurang } \\
\text { Baik }\end{array}$ \\
\hline 2 & 1 & 0 & 0 & 1 & 1 & 3 & 20 & $\begin{array}{l}\text { Kurang } \\
\text { Baik }\end{array}$ \\
\hline 3 & 2 & 2 & 1 & 0 & 0 & 5 & 33,13 & $\begin{array}{l}\text { Kurang } \\
\text { Baik }\end{array}$ \\
\hline 4 & 1 & 0 & 0 & 1 & 0 & 2 & 13,3 & $\begin{array}{l}\text { Kurang } \\
\text { Baik }\end{array}$ \\
\hline 5 & 1 & 0 & 0 & 1 & 0 & 2 & 13,3 & Kurang \\
\hline
\end{tabular}




\begin{tabular}{|c|c|c|c|c|c|c|c|c|}
\hline \multirow[t]{2}{*}{ No. } & \multirow{2}{*}{$\begin{array}{l}\text { Skor } \\
\text { soal) }\end{array}$} & \multicolumn{2}{|c|}{ jawaban } & \multirow{2}{*}{$\begin{array}{l}\text { siswa } \\
4\end{array}$} & \multirow{2}{*}{$\begin{array}{l}\text { (butir } \\
5\end{array}$} & \multirow{2}{*}{$\begin{array}{l}\text { Total } \\
\text { skor }\end{array}$} & \multirow{2}{*}{$\begin{array}{c}\text { Pemahama } \\
\text { n konsep } \\
(\%)\end{array}$} & \multirow{2}{*}{$\begin{array}{c}\text { Kategor } \\
\text { i }\end{array}$} \\
\hline & & 2 & 3 & & & & & \\
\hline & & & & & & & & Baik \\
\hline 6 & 1 & 1 & 0 & 1 & 0 & 3 & 20 & $\begin{array}{l}\text { Kurang } \\
\text { Baik }\end{array}$ \\
\hline 7 & 2 & 0 & 0 & 1 & 0 & 3 & 20 & $\begin{array}{l}\text { Kurang } \\
\text { Baik }\end{array}$ \\
\hline 8 & 1 & 0 & 0 & 1 & 0 & 2 & 13,3 & $\begin{array}{l}\text { Kurang } \\
\text { Baik }\end{array}$ \\
\hline 9 & 2 & 0 & 0 & 1 & 0 & 3 & 20 & $\begin{array}{l}\text { Kurang } \\
\text { Baik }\end{array}$ \\
\hline 10 & 1 & 0 & 0 & 1 & 1 & 3 & 20 & $\begin{array}{l}\text { Kurang } \\
\text { Baik }\end{array}$ \\
\hline 11 & 1 & 0 & 0 & 1 & 1 & 3 & 20 & $\begin{array}{l}\text { Kurang } \\
\text { Baik }\end{array}$ \\
\hline 12 & 2 & 0 & 0 & 1 & 0 & 3 & 20 & $\begin{array}{l}\text { Kurang } \\
\text { Baik }\end{array}$ \\
\hline 13 & 1 & 0 & 0 & 1 & 0 & 2 & 13,3 & $\begin{array}{l}\text { Kurang } \\
\text { Baik }\end{array}$ \\
\hline 14 & 1 & 0 & 0 & 0 & 0 & 1 & 6,7 & $\begin{array}{l}\text { Kurang } \\
\text { Baik }\end{array}$ \\
\hline 15 & 1 & 0 & 0 & 1 & 0 & 2 & 13,3 & $\begin{array}{l}\text { Kurang } \\
\text { Baik }\end{array}$ \\
\hline 16 & 2 & 0 & 0 & 1 & 1 & 4 & 26,66 & $\begin{array}{l}\text { Kurang } \\
\text { Baik }\end{array}$ \\
\hline 17 & 1 & 0 & 0 & 1 & 1 & 3 & 20 & $\begin{array}{l}\text { Kurang } \\
\text { Baik }\end{array}$ \\
\hline 18 & 1 & 0 & 0 & 1 & 1 & 3 & 20 & $\begin{array}{l}\text { Kurang } \\
\text { Baik }\end{array}$ \\
\hline 19 & 1 & 0 & 0 & 1 & 0 & 2 & 13,3 & $\begin{array}{l}\text { Kurang } \\
\text { Baik }\end{array}$ \\
\hline 20 & 1 & 0 & 0 & 2 & 1 & 4 & 26,66 & $\begin{array}{l}\text { Kurang } \\
\text { Baik }\end{array}$ \\
\hline 21 & 2 & 0 & 0 & 0 & 0 & 2 & 13,3 & $\begin{array}{l}\text { Kurang } \\
\text { Baik }\end{array}$ \\
\hline 22 & 1 & 0 & 0 & 0 & 0 & 1 & 6,7 & $\begin{array}{l}\text { Kurang } \\
\text { Baik }\end{array}$ \\
\hline 23 & 1 & 0 & 0 & 1 & 0 & 2 & 13,3 & $\begin{array}{l}\text { Kurang } \\
\text { Baik }\end{array}$ \\
\hline 24 & 2 & 0 & 0 & 1 & 0 & 3 & 20 & $\begin{array}{l}\text { Kurang } \\
\text { Baik }\end{array}$ \\
\hline 25 & 1 & 0 & 0 & 1 & 0 & 2 & 13,3 & $\begin{array}{l}\text { Kurang } \\
\text { Baik }\end{array}$ \\
\hline $\begin{array}{l}\text { Jumlah } \\
\text { skor }\end{array}$ & 32 & 3 & 1 & 23 & 8 & 67 & 446,2 & \\
\hline Skor ideal & 75 & 75 & 75 & 75 & 75 & 375 & & \\
\hline
\end{tabular}




\begin{tabular}{lllllllll}
\hline No. & $\begin{array}{l}\text { Skor } \\
\text { soal) }\end{array}$ & jawaban & siswa & (butir & $\begin{array}{c}\text { Total } \\
\text { skor }\end{array}$ & $\begin{array}{c}\text { Pemahama } \\
\text { n konsep } \\
(\%)\end{array}$ & $\begin{array}{c}\text { Kategor } \\
\text { i }\end{array}$ \\
\cline { 2 - 6 } & $\mathbf{1}$ & $\mathbf{2}$ & $\mathbf{3}$ & $\mathbf{4}$ & $\mathbf{5}$ & & \\
\hline $\begin{array}{l}\text { Persentase } \\
(\%)\end{array}$ & $\begin{array}{l}42,6 \\
6\end{array}$ & 4 & 1.33 & 30.66 & $\begin{array}{l}10.6 \\
6\end{array}$ & 17,86 & & \\
\hline Rata-rata & & & & & & & 17,84 \\
\hline
\end{tabular}

Tabel 7. Data Persentase Pemahaman Konsep Siswa Pada Postes

\begin{tabular}{|c|c|c|c|c|c|c|c|c|}
\hline \multirow[t]{2}{*}{ No. } & \multicolumn{3}{|c|}{$\begin{array}{l}\text { Skor jawabai } \\
\text { soal) }\end{array}$} & \multicolumn{2}{|c|}{ siswa (butir } & \multirow{2}{*}{$\begin{array}{l}\text { Total } \\
\text { postes }\end{array}$} & \multirow{2}{*}{$\begin{array}{l}\text { Pemahama } \\
\text { n konsep } \\
(\%)\end{array}$} & \multirow{2}{*}{$\begin{array}{l}\text { Kategor } \\
\text { i }\end{array}$} \\
\hline & 1 & 2 & 3 & 4 & 5 & & & \\
\hline 1 & 2 & 3 & 3 & 2 & 2 & 12 & 80 & $\begin{array}{l}\text { Sangat } \\
\text { Baik }\end{array}$ \\
\hline 2 & 2 & 3 & 2 & 2 & 2 & 11 & 73 & Baik \\
\hline 3 & 2 & 2 & 2 & 2 & 2 & 10 & 67 & Baik \\
\hline 4 & 3 & 3 & 3 & 2 & 2 & 13 & 87 & $\begin{array}{l}\text { Sangat } \\
\text { Baik }\end{array}$ \\
\hline 5 & 2 & 2 & 2 & 2 & 2 & 10 & 67 & Baik \\
\hline 6 & 2 & 2 & 2 & 2 & 2 & 10 & 67 & Baik \\
\hline 7 & 3 & 2 & 1 & 2 & 3 & 11 & 73 & Baik \\
\hline 8 & 3 & 2 & 1 & 2 & 3 & 11 & 73 & Baik \\
\hline 9 & 3 & 2 & 2 & 2 & 3 & 12 & 80 & $\begin{array}{l}\text { Sangat } \\
\text { Baik }\end{array}$ \\
\hline 10 & 3 & 2 & 2 & 2 & 2 & 11 & 73 & Baik \\
\hline 11 & 3 & 2 & 2 & 2 & 3 & 12 & 80 & $\begin{array}{l}\text { Sangat } \\
\text { Baik }\end{array}$ \\
\hline 12 & 3 & 2 & 1 & 3 & 2 & 11 & 73 & Baik \\
\hline 13 & 2 & 2 & 1 & 2 & 3 & 10 & 67 & Baik \\
\hline 14 & 3 & 3 & 3 & 2 & 2 & 13 & 87 & $\begin{array}{l}\text { Sangat } \\
\text { Baik }\end{array}$ \\
\hline 15 & 2 & 2 & 2 & 2 & 3 & 11 & 73 & Baik \\
\hline 16 & 2 & 3 & 3 & 2 & 2 & 12 & 80 & $\begin{array}{l}\text { sangat } \\
\text { Baik }\end{array}$ \\
\hline 17 & 2 & 2 & 2 & 3 & 2 & 11 & 73 & Baik \\
\hline 18 & 3 & 2 & 1 & 2 & 2 & 10 & 67 & Baik \\
\hline 19 & 2 & 2 & 1 & 2 & 2 & 9 & 60 & Baik \\
\hline 20 & 2 & 3 & 3 & 2 & 2 & 12 & 80 & $\begin{array}{l}\text { sangat } \\
\text { Baik }\end{array}$ \\
\hline 21 & 2 & 3 & 3 & 2 & 2 & 12 & 80 & $\begin{array}{l}\text { Sangat } \\
\text { Baik }\end{array}$ \\
\hline 22 & 2 & 3 & 3 & 2 & 2 & 12 & 80 & $\begin{array}{l}\text { Sangat } \\
\text { Baik }\end{array}$ \\
\hline 23 & 2 & 2 & 2 & 2 & 2 & 10 & 67 & Baik \\
\hline 24 & 2 & 2 & 2 & 2 & 2 & 10 & 67 & Baik \\
\hline 25 & 3 & 2 & 2 & 2 & 2 & 11 & 73 & Baik \\
\hline
\end{tabular}




\begin{tabular}{|c|c|c|c|c|c|c|c|}
\hline $\begin{array}{l}\text { Jumlah } \\
\text { skor }\end{array}$ & 60 & 58 & 51 & 52 & 56 & 277 & 1847 \\
\hline Skor ideal & 75 & 75 & 75 & 75 & 75 & 375 & \\
\hline $\begin{array}{l}\text { Persentas } \\
\mathrm{e}(\%)\end{array}$ & 80 & $\begin{array}{l}77.3 \\
3\end{array}$ & 68 & $\begin{array}{l}69.3 \\
3\end{array}$ & 74.66 & 73.86 & \\
\hline Rata-rata & & & & & & & 73,88 \\
\hline
\end{tabular}

Pengelolaan pembelajaran direkam dengan memberikan tanda cek $(\sqrt{ })$ pada lembar observasi aktivatas pembelajaran. Hasil observasi aktivitas pengelolaan pembelajaran dapat dilihat pada lampiran. Kualitas aktivitass pengelolaan pembelajaran dibagi menjadi 4 kategori, sesuai kriteria halaman dengan rentang skor 0-39 (kurang baik), skor 40-59 (cukup baik), skor 60-79 (baik), dan skor 80100 (sangat baik). Hasil observasi pengamatan tersebut memperlihatkan bahwa secara keseluruhan kualitas aktivitas pengelolaan pembelajaran yang dilakukan termasuk dalam kategori baik dengan presentase $89,06 \%$.

\section{Deskripsi Aktivitas Kelompok Siswa dalam Pembelajaran Menggunakan} Model Discovery Learning Berbantuan LKS

Aktivitas belajar kelompok dibagi menjadi 4 kategori, sesuai kriteria halaman dengan rentang skor 0-39 (kurang baik), skor 40-59 (cukup baik), skor 60-79 (baik), dan skor 80-100 (sangat baik).

Tabel 8. Skor Aktivitas Belajar Kelompok

\begin{tabular}{|c|c|c|c|c|c|c|}
\hline \multirow[b]{2}{*}{$\begin{array}{l}\text { Kelo } \\
\text { mpok }\end{array}$} & \multicolumn{4}{|c|}{ Aspek yang dinilai } & \multirow[b]{2}{*}{$\begin{array}{c}\text { Nilai } \\
\text { konver } \\
\text { si }(\%)\end{array}$} & \multirow[b]{2}{*}{$\begin{array}{c}\text { Kateg } \\
\text { ori }\end{array}$} \\
\hline & $\begin{array}{c}\text { Mengana } \\
\text { lisis data } \\
\text { dan } \\
\text { menentu } \\
\text { kan } \\
\text { konsep }\end{array}$ & $\begin{array}{c}\text { Mengko } \\
\text { munikasi } \\
\text { kan } \\
\text { konsep } \\
\text { yang } \\
\text { diperole } \\
\text { h }\end{array}$ & $\begin{array}{c}\text { Mengkomu } \\
\text { nikasikan } \\
\text { penerapan } \\
\text { konsep } \\
\text { yang } \\
\text { diperoleh }\end{array}$ & Kerjasama & & \\
\hline $\mathrm{I}$ & 3 & 4 & 3 & 4 & 70 & Baik \\
\hline II & 3 & 4 & 3 & 4 & 70 & Baik \\
\hline III & 3 & 4 & 3 & 4 & 70 & Baik \\
\hline IV & 4 & 4 & 3 & 4 & 75 & Baik \\
\hline $\mathrm{V}$ & 4 & 4 & 4 & 4 & 80 & $\begin{array}{c}\text { Sangat } \\
\text { Baik }\end{array}$ \\
\hline
\end{tabular}

\section{Pembahasan}

\section{Analisis Peningkatan Pemahaman Konsep Siswa}

Peningkatan pemahaman konsep didasarkan pada data hasil pretes dan postes siswa. Butir soal pada pretes dan postes mewakili konsep-konsep kelarutan dan hasilkali kelarutan, dimana setiap butir soal pretes dan postes memiliki kriteria penskoran. Total skor yang didapatkan siswa ini dikonversikan dalam bentuk persentase pemahaman dan kemudian diklasifikasikan tingkat pemahaman siswa. Pemahaman konsep siswa pada setiap indikator dapat ditelusuri dengan menganalisis pola jawaban dalam hasil pekerjaan siswa dari pretes dan postes. Peningkatan pemahaman konsep siswa setiap indikator dapat dilihat pada Tabel . 
Tabel 9. Peningkatan Pemahaman Konsep Siswa

\begin{tabular}{|c|c|c|c|c|c|}
\hline \multirow[t]{2}{*}{ Indikator } & \multirow{2}{*}{$\begin{array}{l}\text { Butir } \\
\text { Soal }\end{array}$} & \multicolumn{2}{|c|}{$\begin{array}{l}\text { Pemahaman } \\
\text { Konsep }(\%)\end{array}$} & \multirow{2}{*}{$\begin{array}{l}\text { Perubahan } \\
\text { Pemahaman Konsep } \\
(\%)\end{array}$} & \multirow[t]{2}{*}{ Kategori } \\
\hline & & Pretes & Postes & & \\
\hline I & 1 & 42,66 & 80 & 65,11 & Sedang \\
\hline II & 2 & 4 & 77,33 & 76,38 & Tinggi \\
\hline III & 3 & 1,33 & 68 & 67,56 & Sedang \\
\hline IV & 4 & 30,66 & 69,33 & 55,76 & Sedang \\
\hline V & 5 & 10,66 & 74,66 & 71,64 & Tinggi \\
\hline Rata-rata & & 17,86 & 73,86 & 67,29 & Sedang \\
\hline
\end{tabular}

Persentase kemampuan siswa dari rata-rata semua indikator dari saat pretes $17,86 \%$ menjadi $73,86 \%$ saat postes, sehingga terjadi presentase rata-rata perubahan pemahaman siswa adalah sebesar $67,29 \%$. Grafik besarnya persentase pemahaman konsep siswa pada saat pretes dan postes untuk setiap indikator dapat dilihat pada

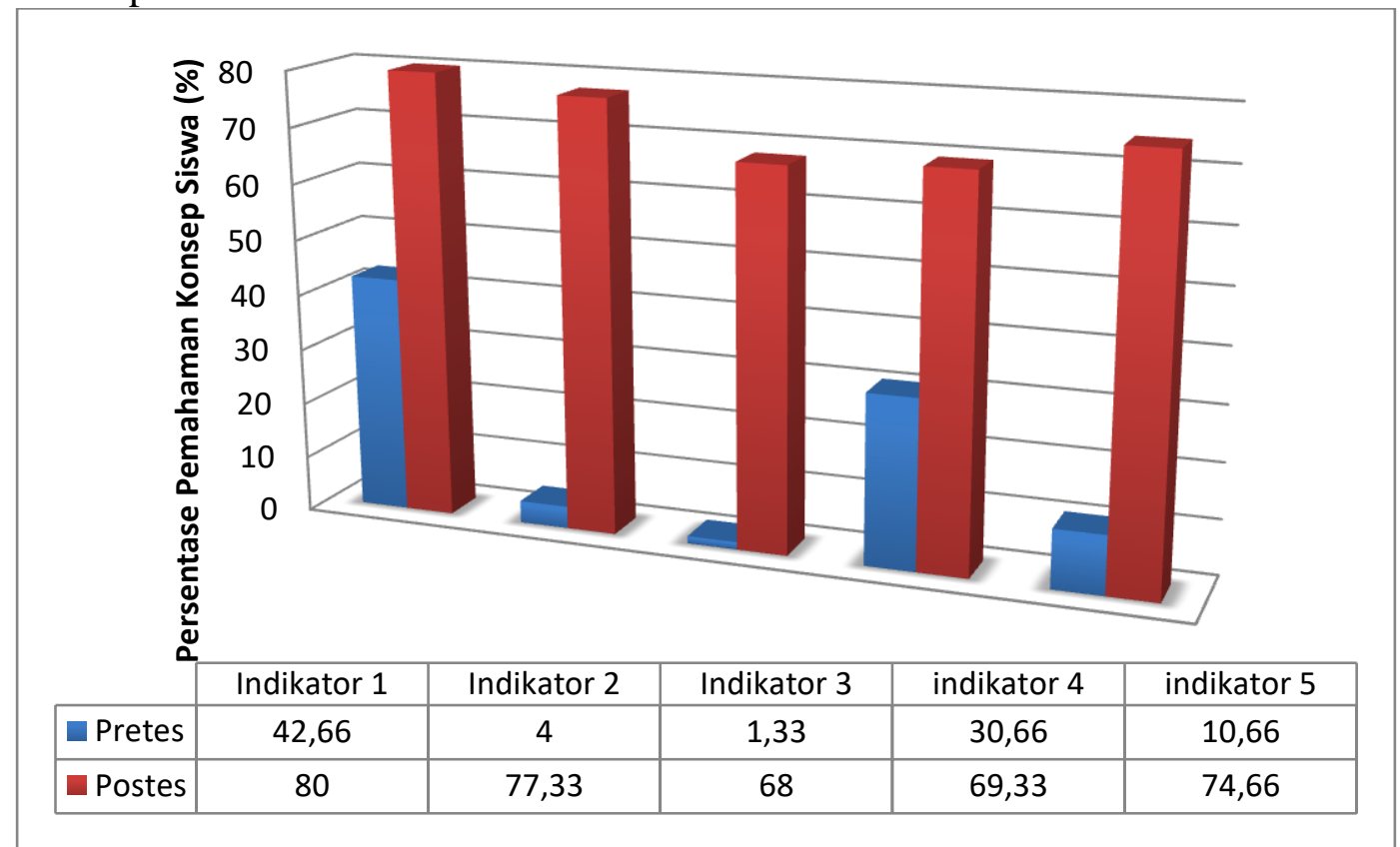

Gambar 1. Grafik Persentase Pemahaman Konsep Siswa untuk Setiap Indikator Grafik Persentase Pemahaman Konsep Siswa untuk Setiap Indikator

Peningkatan skor pretes siswa dimulai dengan nilai terendah dan tertinggi terhadap KKM dapat digambarkan dalam sebuah kurva. Kurva nilai pretes dan postes terhadap KKM menunjukan tingkat ketuntasan siswa disajikan pada Gambar 1 . 


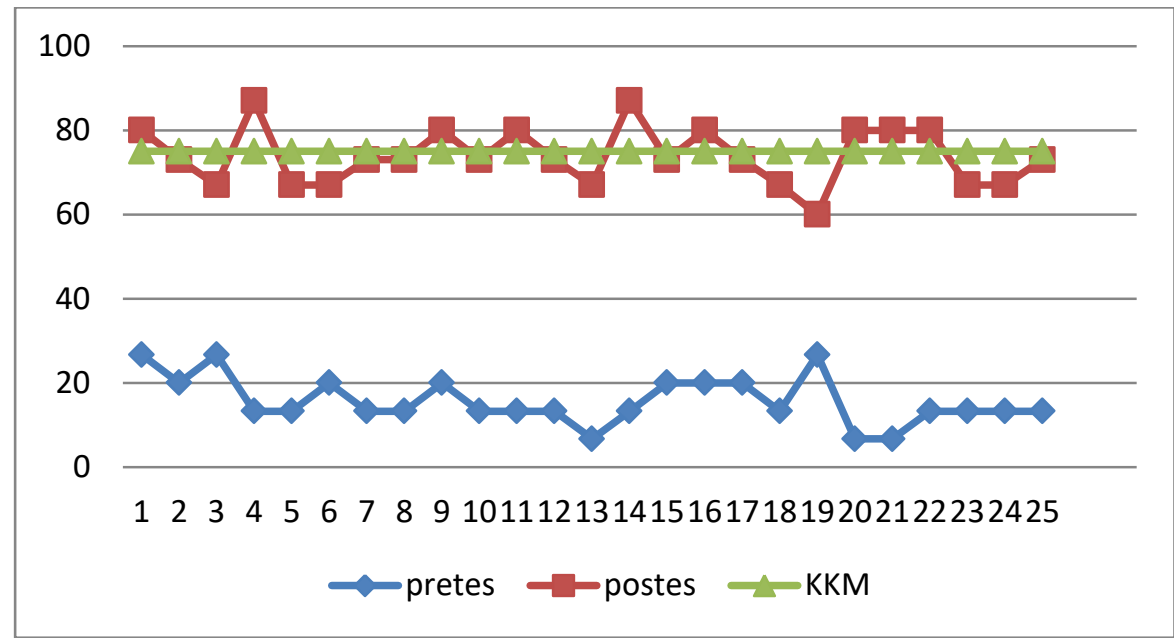

Gambar 2. Kurva Nilai Pretes dan Postes Terhadap KKM

\section{SIMPULAN}

Berdasarkan hasil penelitian dan analisis data dapat disimpulkan bahwa pemahaman konsep struktur atom setelah pembelajaran menggunakan model Discovery Learning berbantuan LKS adalah:

1) Siswa menjelaskan dan menuliskan simbol atom sebagai lambang unsur yang dilegkapi dengan nomor atom dan nomor massa. Jumlah siswa yang pemahaman konsepnya benar tentang menuliskan dan menjelaskan simbol atom sebagai lambvang unsur berjuml;ah $80 \%$.

2) Siswa mendeskripsikan pengertian nomor atom, (jumlah proton) sebagai identitas atom suatu unsur. Jumlah siswa yang pemahaman konsepnya benar tentang mendeskripsikan pengertian nomor atom, (jumlah proton) sebagai identitas atom suatu unsur berjumlah $77,33 \%$.

3) Siswa mendeskripsikan pengertian nomor massa sebagai jumlah proton dan neutron dalam suatu inti atom. Jumlah siswa yang pemahaman konsepnya benar tentang mendeskripsikan pengertian nomor massa sebagai jumlah proton dan neutron dalam suatu inti atom berjumlah $68 \%$

4) Siswa menuliskan nomor massa, jumlah neutron, dan jumlah elektron pada unsur yang diketahui notasinya. Jumlah siswa yang pemahaman konsepnya benar tentang nomor massa, jumlah neutron, dan jumlah elektron pada unsur yang diketahui notasinya berjumlah $69,33 \%$.

5) Siswa menjelaskan pengertian isotop, isoton, dan isobar. Jumlah siswa yang pemahamannya benar tentang pengertian isotop, isoton, dan isobar. berjumlah $74,66 \%$

Rata-rata pemahaman konsep siswa kelas X-MIA 1 SMA Negeri 1 Paku Barito Timur Tahun Ajaran 2017/2018 dengan pembelajaran menggunakan Model Discovery Learning berbantuan LKS pada materi struktur atom adalah sebesar $73,86 \%$ yang dinyatakan dalam kategori baik.

\section{UCAPAN TERIMA KASIH}

Terima kasih saya ucapkan kepada semua pihak yang telah membantu dan mendukung saya dalam menyelesaikan tugas akhir skripsi saya, sehingga dapat terselesaikan. 


\section{DAFTAR RUJUKAN}

Arifin, Mulyati. (2000). Strategi Belajar Mengajar Kimia. Bandung: Universitas Negeri Malang

Dahar, R. W. (1989). Teori-teori Belajar. Jakarta: Erlangga

Depdiknas. (2003). Kurikulum Kimia 2004. Jakarta: Departemen Pendidikan dan Kebudayaan Direktorat Jenderal Pendidikan Tinggi Proyek Pembimbingan Tenaga Kependidikan.

Gina Pebria Leloni,2015. Pengaruh Pemberian LKS Terhadap Pemahaman Konsep Tata Nama Senyawa dan Persamaan Reaksi Pada Siswa Kelas XI SMA Negeri 2 Palangka Raya Tahun Ajaran 2014/2015. Skripsi Sarjana, tidak diterbitkan, Universitas Palangka Raya.

Husaini Usman. (2003). Metodologi Penelitian.Jakarta: Bumi Askara.

Keenan,Charles W, dkk. 1992. Kimia untuk Universitas Jilid 2. Jakarta: Erlangga.

Kosasi, E. 2014. Strategi Belajar dan Pembeajaran Implementasi Kurikulum 2013. Bandung: Yrama Widya.

Kunandar. 2014. Penilaian Autentik (Penilaian Hasil Belajar Peserta Didik Berdasarkan Kurikulum 2013). Jakarta: PT. Rajagrafindo Persada.

Meiliawati, R. 2019. Pemahaman Konsep Sifat Jari-Jari Atom Dan Keelektronegatifan Pada Mahasiswa Pendidikan Kimia Semester IV Tahun Ajaran 2016/2017 Hasil Pembelajaran Menggunakan Model Discovery Learning. Jurnal Ilmiah Kanderang Tingang. 10, 1 (Jun. 2019), 38-45.

Rapita Sari, (2016). Pemahaman Konsep Kelarutan dan Hasil kali Kelarutan Pasca Pembelajaran Menggunakan Model Discovery Learning Berbantuan LKS pada Siswa Kelas XI MIA-4 SMA Negeri 4 Palangka Raya Tahun Ajaran 2015/2016. Skripsi. Tidak diterbitkan: Universitas Palangka Raya.

Undang-Undang Nomor 20 Tahun 2003 tentang Sistem Pendidikan Nasional. Jakarta: Depdiknas.

Undang-Undang Nomor 14 Tahun 2005 tentang Guru dan Dosen. Jakarta: Depdiknas.

Tim Penyusun Pedoman Penulisan Karya Ilmiah. 2014. Pedoman Penulisan Karya Ilmiah. Palangka Raya : FKIP UPR 